\title{
PREFERENSI POLITIK PADA PEMILIHAN KEPALA DAERAH (PILKADA) DI KOTA MADIUN
}

\author{
Agus Prasetya \\ Fakultas Keguruan dan Ilmu Pendidikan \\ Universitas Terbuka \\ http://doi.org/10.21107/pmt.v11i2.4757
}

\begin{abstract}
Abstrak
Fakta sosial menunjukkan bahwa proses demokrasi lokal yang seharusnya berjalan dengan baik dan benar sesuai dengan tujuannya yaitu untuk meningkatkan partisipasi politik rakyat / masyarakat untuk memilih pemimpinnya ternyata belum membuahkan hasil yang maximal. Dimana para elite politik lokal dan partai melakukan polarisasi pendukungnya dalam menentukan pilihan seorang calon kepala daerah dan berbagai cara. Sehingga menimbulkan perilaku politik pemilih yang tidak murni dari hati nuraninya tetapi dipaksakan agar memilih sesuai dengan kehendak pimpinannya dengan imbalan tertentu. Pemilihan Kepala daerah sebagai kegiatan politik lokal dilaksanakan dengan berdasarkan Undangundang No 2 tahun 2011 yang kemudian direvisi dengan UU No.07/ tahun 2017 tentang pemilu yang di dalamnya mengatur tentang pengaturan pemilihan kepala daerah yang didalamnya tentang pemilihan, pengesahan, pengangkatan, serta dalam pemberhentian kepala daerah.Penelitian ini menggunakan metode penelitian kualitatif, dimana fokus penelitiannya menggunakan pendekatan studi kasus. Penelitian ini dengan pendekatan kualitatif adalah salah satu prosedur penelitian yang menghasilkan data diskriptif berupa ucapan, atau tulisan dan perilaku calon walikota yang diamati.Pendekatan kualitatif diharapkan menghasilkan uraian yang mendalam tentang ucapan, perilaku, yang dapat diamati dari para calon walikota. Tehnik pengambilan data penelitian ini dengan tehnik wawancara mendalam (indepth interview ) melalui snowball pada pemilih yang ada di daftar pemilih tetap. Untuk mendukung pelaksanaan penelitian, peneliti menggunakan kajian teori antara lain, teori pertukaran Sosial, teori Perilaku Sosial dan teori tindakan Sosial.
\end{abstract}

Kata Kunci : pilkada, perilaku politik, preferensi politik, calon wali kota, modal sosial, modal ekonomi

\section{PENDAHULUAN}

Pemilihan umum kepala daerah sebagai kegiatan politik lokal di daerah dilaksanakan berdasarkan Undangundang No. 2 tahun 2011, kemudian direvisi dengan Undang-undang No 07/2017 tentang pemilihan umum didalamnya mengatur tentang pemilihan kepala daerah. Fakta sosial menunjukkan bahwa proses demokrasi lokal yang seharusnya baik dan benar sesuai dengan tujuannya yaitu meningkatkan partisipasi politik rakyat untuk memilih pemimpinnya ternyata belum membuahkan hasil yang maksimal dimana para elite politik lokal dan partainya melakukan polarisasi pemilih dalam menentukan calon wali kota maupun wakil wali kotanya.

Polarisasi pemilih, sudah barang tentu menunjukkan hakekat demokrasi yang hakiki dan kedewasaan belum terjadi dalam proses pemilihan kepala daerah. Proses yang nampak adalah demobilisasi massa dan rekayasa sosial politik elite politik partai, sehingga perilaku politik masyarakat tidak berkualitas dan cenderung tidak rasional. Perilaku politik (political behaviour) adalah perilaku politik yang dilakukan insan individu atau kelompok guna memenuhi hak dan kewajiban sebagai insan politik. Setiap individu diwajibkan oleh negara untuk melakukan hak, kewajiban guna melakukan perilaku politiknya. Dalam 
pemilihan umum kepala daerah diseluruh Indonesia terindikasi adanya politik uang oleh calon pimpinan daerah hal tersebut menunjukan perilaku menyimpang dari pemilih walaupun bukti-bukti sulit dibuktikan, sehingga hasil pemilu tetap sah secara hukum.

Pada tahun 2019, sesuai pleno KPU direncanakan pemilu nasional untuk memilih presiden, DPR/MPR, dan pada tahun 2018 ada sekitar 200 (KPU :2017) pilkada di tingkat Kabupaten/ Kota serta propinsi harus melaksanakan pilkada. Informasi di masyarakat banyak issue yang berkembang tentang mentalitas perilaku politik warga, ketidakjujuran menjelang pemilih umum. Perbuatan menyimpang, seperti politik uang, korupsi, jual beli jabatan posisi jabatan terjadi menjelang pilkada, ada politik uang oleh calon kepala daerah, calon gubernur di beberapa daerah, bahkan ada yang fantastik jumlah.

Terdapat beberapa daerah yang bupati, walikota, serta calon gubernur nya tertangkap basah oleh Operasi Tangkap Tangan (OTT) KPK karena kasus korupsi. Kasus OTT yang menimpa calon walikota, bupati dan gubernur karena perilaku politik menyimpang bakal calon untuk mencari modal dalam Pilkada. Pada waktu pemilihan umum daerah pertama tahun 2015-an, banyak pemilih yang salah menggunakan hak pilihnya karena terjadinya money politik yang menyebabkan banyak pemilih keliru dalam menggunakan hak pilihnya sehingga masyarakat dibodohi oleh oknum hingga akhirnya menentukan pilihan tertentu karena adanya serangan Fajar bagi-bagi "angpao". Hal tersebut tidak boleh lagi terjadi karena berdampak pada kualitas pemilu menurut undang-undang No. 17./ tahun 2017.

Terdapat empat alasan penting mengapa perilaku politik pemilih pada saat pilkada langsung perlu dikaji secara mendalam, di era otonomi daerah, (1) pilkada kali ini merupakan pemilu serentak yang di ikuti banyak daerah di era reformasi yang perlu dicermati dalam rangka menegakkan sendi-sendi demokrasi. Dan sebagai barometer politik, sosial ekonomi, demokrasi di otonomi daerah sedang dicermati sehingga pelaksanaan pilkada yang aman, damai, jujur, demokratis, langsung, umum, bebas, rahasia, lancar, jujur sangat diperlukan. Sebab setalah pilkada 2018 secara serentak akan dilaksanakan pemilihan perisden dan wakil presiden pada tahun 2019, sehingga posisi pilkada saat ini sangat srtategis dan penting bagi bangsa dan negara Indonesia; (2) bangsa Indonesia merupakan bangsa yang Bhineka Tunggal Ika dalam soal budaya lokal seperti banyaknya suku bangsa yang sangat pluralis/majemuk. Hal ini mempunyai tingkat kerawanan yang tinggi dalam social politik khususnya dalam pilkada saat ini, jika tidak dikelola dengan baik dapat berakibat disintegrasi bangsa. Hal tersebut disebabkan oleh preferensi politik pemilih yang tidak faham politik di era reformasi; (3) muncul politik uang dari calon-calon pemimpin daerah dalam pilkada, dan belum adanya audit modal / keuangan para calon pimpinan daerah dalam pilkada secara transparan. Sehingga politik uang menjadi faktor yang mewarnai pelaksanaan pilkada selama ini, figur calon baik berkualitas dapat kalah dengan adanya politik uang, hal inilah yang menjadi koreksi pemerintah dan DPR sehingga ada aturan yang tegas tentang politik uang; (4) pelaksanaan pilkada saat ini masih menyisakan pekerjaan rumah yang memprihatinkan kaitannya dengan sendi-sendi demokrasi sebagaimana dengan maksud dan tujuan awal Undang-undang No.07/ tahun 2017.

Dengan preferensi politik calon pemilih yang menyimpang membuat pemilihan kepala daerah akan menghasilkan pemimpin yang tidak amanah, pilkada akhirnya gagal total karena perilaku politik calon pimpinan daerah yang melanggar UU, curang, menciderai demokrasi. Kasus tertangkapnya beberapa kepala daerah merupakan indikasi adanya perilaku politik calon walikota, bupati, gubernur yang melanggar UU. Penangkapan pejabat daerah yang mencalonkan diri untuk mengikuti pilkada memberikan indikasi bahwa mereka calon tersebut mencari modal ekonomi untuk biaya pilkada. Idealnya suatu kompetisi untuk meraih suatu prestasi dalam ajang perlombaaan, seharusnya tidak boleh seorang calon pimpinan berbuat curang 
dengan korupsi, sebab mereka adalah calon kepala daerah pemegang amanah. Sedangkan sekarang yang terjadi calon peserta pilkada "rame-rame" mencari modal atau uang untuk pilkada dengan cara yang salah yakni jual beli jabatan, memakan uang negara dengan korupsi.

Perilaku Politik adalah perilaku yang dilakukan oleh insan atau ndividu kelompok guna memenuhi hak dan kewajiban nya sebagai insan politik. Seorang individu atau kelompok diwajibkan oleh negara untuk melakukan fungsi sosial politik, hak dan kewajibannya guna menyalurkan aspirasi politik.Yang dimaksud dengan perilaku politik adalah (Chaplin, 1993) : (1) melakukan pemilihan untuk memilih calon pemimpin wakil rakyat. (2) mengikuti dan berhak menjadi insan politik yang mengikuti suatu partai politik, mengikuti ormas atau LSM.(3) ikut serta dalam pesta politik. (4) ikut mengritik atau menurunkan para pelaku politik yang berotoritas. (5) berhak menjadi calon pimpinan politik.(6) berkewajiban untuk melakukan hak dan kewajibannya sebagai insan politik guna melakukan perilaku politik yang telah disusun secara baik oleh konstitusi Undang-Undang Dasar 1945 dan peraturan perundangan yang berlaku.Secara bebas perilaku politik adalah diartikan keseluruhan tingkah laku politik para aktor politik dan warga negara dalam manivestasi konkritnya telah saling memiliki hubungan dengan kultur.Sikapsikap warga negara, respon dalam menilai terhadap obyek dan peristiwa politik maupun aktifitasnya terhadap sistem politik yang ada saat ini sangat dipengaruhi pula oleh preferensi perilaku elite politik yang memerintah maupun kehidupan sosial budaya masyarakat. (Powel dalam Prawira, 1985).

Penelitian ini ingin mengexplore masalah preferensi politik pemilih tentang apa yang mereka lakukan dalam perjalanan berkompetisi dalam pilkada, sehingga tindakan social politik pemilih tidak melanggar aturan perundangundangan. Pada tanggal 27 Juni 2018 secara serentak dilaksanakan pilkada di daerah kota/ kabupaten dan tingkat provinsi yang diikuti oleh 200 kepala daerah di seluruh Indonesia (KPU, 2017). Secara umum setiap hari masyarakat di suguhi berita-berita tentang preferensi politik pemilih yang mengikuti pemilihan kepala daerah, kebanyakan kasus yang terekspos yakni masalah moneypolitic dan dapat apa jika memilih calon tertentu dengan masalah uang, hal tersebut ditengarahi karena masalah modal social ekonomi. Tujuan dari penelitian ini adalah (1) mendeskripsikan preferensi politik pemilih calon wali kota pada pilkada tahun 2018; (2) mengetahui preferensi politik pemilih terhadap calon walikota kota Madiun; dan (3) menganalisa faktor-faktor yang menyebabkan preferensi politik pemilih terhadap calon walikota.

\section{METODOLOGI}

\section{- Pendekatan Rancangan Penelitian}

Jenis penelitian ini adalah kualitatif, yaitu penelitian yang bermaksud untuk memahami fenomena tentang apa yang dialami oleh subyek, misalnya penelitian perilaku, persepsi, motivasi, tindakan, secara holistik dengan cara deskripsi dalam bentuk kata-kata dan bahasa, pada suatu konteks khususnya yang alamiah dengan memanfaatkan berbagai metode alamiah. Penelitian deskriptif yaitu sebuah penelitian yang berusaha mengumpulkan informasi mengenai suatu tema, gejala atau keadaan menurut apa adanya untuk menemukan pengetahuan yang seluasluasnya terhadap obyek penelitian. Penelitian diskriptif pada umumnya dilakukan dengan tujuan utama, yaitu menggambarkan secara sistematis fakta dan karakteristik obyek atau subyek yang di teliti secara tepat (Sukardi, 2003).

Teknik pengumpulan data pada penelitin ini dilakukan dengan beberapa cara yaitu a) teknik observasi, b) teknik wawancara c) teknik studi dokumentasi. Model pengolahan data yang digunakan dalam penelitian ini menggunakan model Interactive dari Miles dan Huberman yaitu: data collection, data reduction, data display dan conclusion drawing/verification seperti dilukiskan pada Gambar 3.1. 


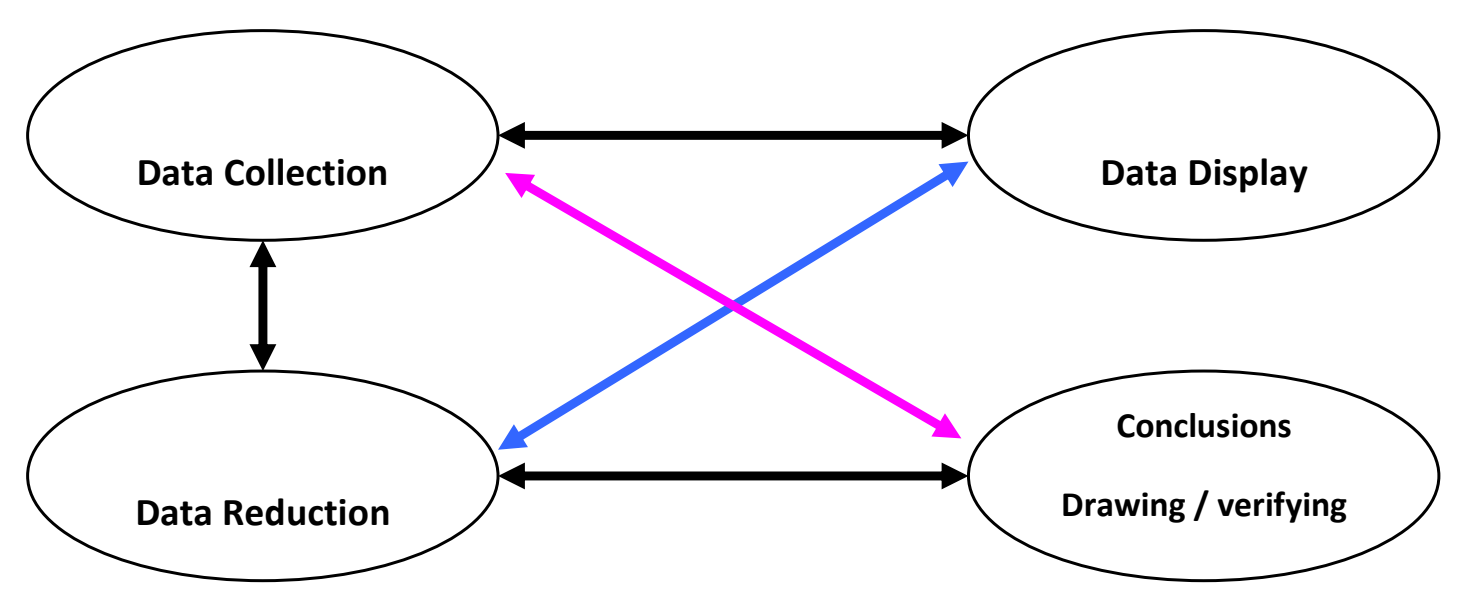

Gambar 1. Pengolahan data Model Interactive Miles dan Huberman

\section{HASIL DAN PEMBAHASAN}

Realisasi dalampemberlakukan Undang-undang Nomor 07 tahun 2017 tentang pemilihan umum merupakan tonggak baru dalam demokrasi di Indonesia. Sebab UU tersebut memiliki filosofi, paradigma yang berbeda dengan UU sebalumnya. UU No 02/ 2011 tentang pokok-pokok pemilihan umum.Undangundang tersebut menggunakan filosofi keseragaman dalam kesatuan, maka UU No 07/ tahun 2017 menggunakan filosofi keaneka ragaman dalam kesatuan. UU tersebut direvisi untuk pemilu serentak tahun 2018. Perubahan paradigma penyelenggaraan pilkada, pada dasarnya adalah adanya pilkada kepala daerah dan wakil kepala daerah secara langsung oleh masyarakat. Pilkada sebagai sarana untuk pelaksanaan kedaulatan rakyat di wilayah NKRI berdasarkan UUD 1945 dan Pancasila untuk memilih kepala dan wakil kepala daerah dengan tahap-tahap sbb : a) penetapan pemilih b) pendaftaran pemilih. c) penelitian pasangan calon.d) penetapan dan pengumuman calon.e) pelaksanaan kampanye. g) bentuk,variasi kampanye. h) larangan kampanye. i) dana kampanye. j ) pemungutan dan perhitungan suara. k) penetapan calon. l)pengesahan dan pengnangkatan dan pelantikan calon. Pentahapan dalam PP Nomor 6 tahun 2005 sebagai acuan dalam memberikan gambaran tehadap proses pelaksanaan pemilihan kepala daerah.
Untuk mengupas permasalahan dalam preferensi politik pemilih pada pilkada ke 4 di kota Madiun, dibawah beberapa untuk meng-explore data dalam pilkada tersebut antara lain :

\section{a.Teori Tindakan Sosial}

Teori tindakan sosial digunakan oleh penulis untuk menganalisis preferensi perilaku politik pemilih. Preferensi perilaku politik pemilih sebagai tindakan sosial merupakan suatu proses yang dimana aktor terlibat dalam pengambilanpengambilan keputusan subyektif tentang sarana dan cara untuk mencapai tujuan tertentu yang telah dipilih, tindakan tersebut setiap jenis perlaku manusia, yang penuh arti di orientasikan pada perilaku orang lain. Menurut Weber, tindakan sosial adalah tindakan yang mempunyai makna subyektif bagi dan dari aktor pelakunya, atas dasar tindakan social tradisional, tindakan social Rasional, tindakan social ada tujuan tertentu, dan tindakan social bermotive tertentu. (Weber, 1986).

Tindakan-tindakan sosial untuk untuk mencapai harapan-harapan dalam aktifitas sosial politik, tindakan yang didasari oleh kesadaran keyakinan mengenai nilai-nilai (wert) seperti etika, estetika, agama dan nilai-nilai lainnya yang dapat mempengaruhi tingkah laku manusia dalam kehidupannya, tindakan yang ditentukan oleh kondisi kejiwaan dan perasaan aktor yang melakukannya. Dan tindakan yang didasarkan kebiasaankebiasaan yang telah mendarah daging dalam kehidupannya. (Johson, 1986). 


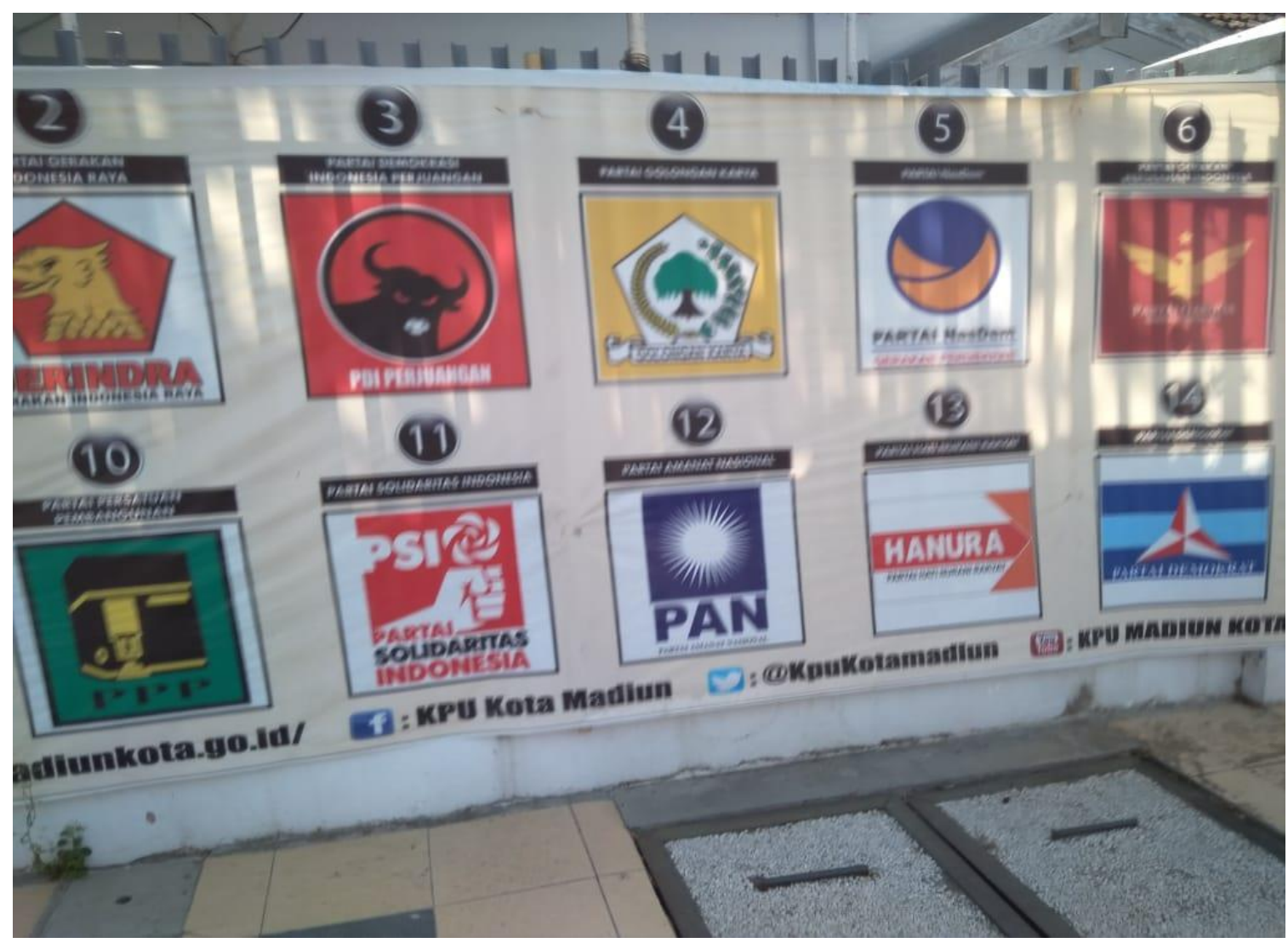

Gambar 2. Poster Partai Peserta Pemilu Tahun 2018 Kota Madiun Hasil Penilaian Factual KPU Jakarta yang Mengikuti Pelaksanaan Pemilihan Kepala Daerah 2018 dan Pemilihan Presiden 2019.

\section{b. Teori Perilaku (Behaviuoral Theory)}

Menurut Blau (1964), pertukaran perilaku merupakan dasar dari bagian besar hubungan-hubungan sosial, akan tetapi terdapat perbedaan yang mendasar diantara pertukaran seperti itu terdapat dalam organisasi sosial yang kompleks. Teori pertukaran perilaku sosial Peter Blau tersebut sangat relevan dengan fungsionalisme struktural, akan tetapi lebih memperhatikan fenomena perubahan sosial dari pada fungsionalisme klasik. Blau (1964) menunjuk empat hal. Komponen atau dimensi perubahan perilaku sosial dari lapangan reduksionisme psikologis menempatkan dalam lapangan sosiologis yang dapat digunakan sebagai dasar bahas "pertukaran perilaku dan kekuasaan dalam organisasi-organisasi besar" tetapi teorinya berlandaskan premis bahwa perilaku manusia ditentukan oleh pertukaran.

Tindakan dan perilaku politik individu ditentukan oleh pola orientasi umum yang tampak secara jelas sebagai pencerminan budaya politik. Segala sesuatu bentuk ucapan, pernyataan, tingkah laku, bahkan, mitos sekalipun sebenarnya dapat diungkapkan sebagai akibat pola dan budaya politik. Dengan demikian segala sesuatu perilaku seseorang aktor politik merupakan para meter dalam melihat bagaimana sikap individu itu bergaul dan berkumpul. Aktor-aktor politik menurut Surbakti (1992) dapat dibagi menjadi 2 (dua) yakni: (1) bertipe pemimpin yang mempunyai tanggung jawab atau tugas dan kewenangan untuk membuat dan melaksanakan keputusan politik. (2) Warga masyarakat biasa yang mempunyai hak dan kewajiban untuk mengajukan tuntutan serta dukungan terhadap aktor politik bertipe pertama, termasuk mengajukan aspirasi, kepentingan atau mengajukan alternatif putusan berlainan dengan keputusan yang telah dibuat aktor politik tipe pertama.

Salah satu substansi dasar yang berkaitan dengan preferensi perilaku politik 
adalah pendekatan tingkah laku politik lebih menjadi titik sentral perhatian dari pada lembaga-lembaga politik atau kekuasaan dan keyakinan politik. Hal ini disebabkan oleh tingkah laku politik calon kepala daerah merupakan pencerminan dari budaya politik masyarakat yang sarat dengan aneka macam bentuk karakter dan aneka bentuk kelompok dengan aneka macam perilakunya. Preferensi perierilaku politik tidak ditentukan oleh situasi temporer, akan tetapi mempunyai pola yang berorientasi pada pola umum yang nampak jelas sebagai pencerminan budaya politik yang sering kali disebut sebagai peradaban politik. Jadi preferensi perilaku politik tumbuh atas dasar kesadaran yang mendalam tentang sistem politik yang berlaku atau idologi politik suatu negara ( Budiarjo, 1982).

Pokok preferensi perilaku politik yang disampaikan yang disampaikan oleh kaum "behavioralisme" adalah tentang pendekatan preferensi perilaku politik pemilih dari segi tingkah laku dengan konsep pemikiran sebagai berikut :

1. Tingkah laku politik pemilih dalam pilkada memperlihatkan kesatuan integritas yang dirumuskan dalam generalisasi.

2. Generalisasi-generalisasi pada dasarnya harus dapat dibuktikan/ verivication kebenarannya dengan menunjukkan tingkah laku pemilih yang relevan.

3. Untuk mengumpulkan, menafsirkan data diperlukan tehnik penelitian yang cermat.

4. Untuk mencapai kecermatan dalam penelitian sedapat mungkin tidak main peran.

5. Penelitian politik mempunyai sikap terbuka terhadap konsep teori dan ilmu sosial lainnya.

6. Dalam membuat analisis politik nilai-nilai pribadi si peneliti sedapat mungkin tidak main peran (Valuefree) Budiharjo. 1982:136)

Berdasarkan uraian tersebut diatas, preferensi perilaku politik dalam penelitian ini adalah perilaku politik pemilih yakni aktivitas-aktivitas sosial politik pemilih dalam memberi keputusan politik pilihannya ketika diselenggarakan kan pemilihan kepala daerah secara langsung di Madiun periode 2018-2023.

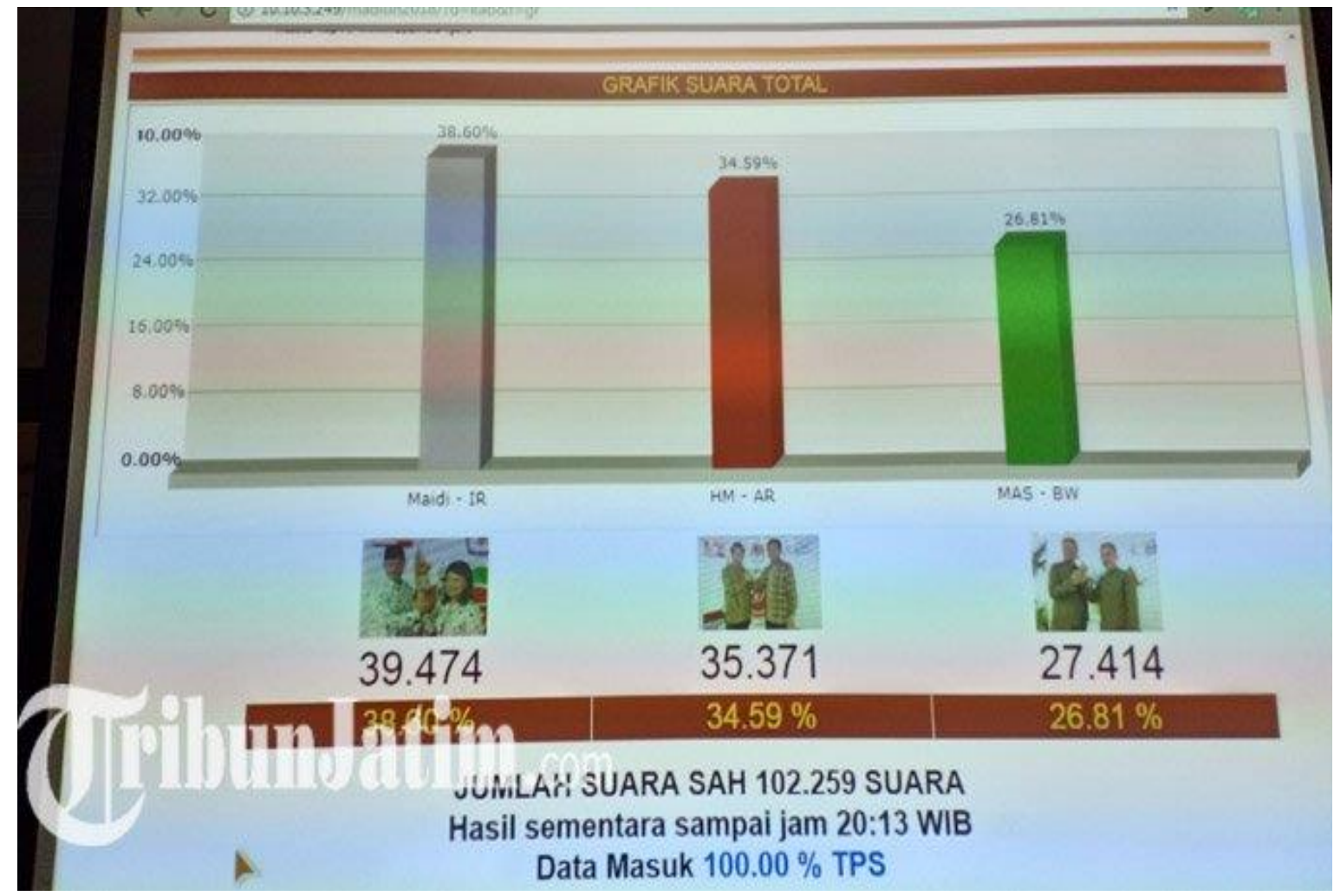

Gambar 3. Hasil Pemungutan Suara Walikota Madiun 2018 
Preferensi perilaku politik yang dimaksud peneliti bahwa preferensi perilaku politik yaitu keputusan pilihan dalam aktifitas politik meliputi keseluruhan tingkah laku politik para aktor politik warga negara/ masyarakat yang dalam manivestasi konkritnya telah saling memiliki hubungan dengan kultur politiknya atau budaya politik masyarakatnya. Preferensi tinngkah laku warga masyarakatnya sebagai respon dalam menilai obyek dan peristiwa politik maupun model perilaku politik nya terhadap sistem politik yang ada.

Setelan melalui tahap-tahap pelaksanaan pilkada, pada tanggal 27 November 2018, diadakan pemungutan suara yang diikuti oleh 144.026 pemilih tetap /DCT KPU 2018 Kota Madiun, diperoleh hasil pemungutan suara secara final yaitu: Maidi - Indah Raya 39,474 / $39,60 \%$ Mahardika-Arif Rahman : 35.37/ $34.59 \%$ dan Yusuf-Rohana : 27.414/ $26.81 \%$. (Sumber : KPU 2018).

Hasil perolehan suara seperti diatas, menunjukkan bahwa masing-masing pasangan calon sama-sama kuat, dengan perbedaan suara yang relative sedikit. Ketua KPU Sasongko menyampaikan andaikata ditambah seminggu, mungkin pasangan Maidi-lda Raya bisa kalah. Preferensi politik pemilih pada Pilkada di Kota Madiun, menunjukkan bahwa preferensi politik pemilih berpihak kepada kekuatan modal social, modal politik, modal ekonomi, modal ketokohan, modal birokrasi, modal komunikasi sosial yang lihai oleh pasangan calon.

Teori Pertukaran Sosial Peter Blau terbukti dalam pilkada pada tanggal 27 Juni 2018 bahwa pemilih menentukan pilihannya atas dasar " saya dapat jika memilih calon, ada suara harus ada imbalannya". Imbalan yang didapat pemilih dapat berupa langsung contoh money politik atau janji-janji yang besok akan di bayar oleh calon walikota sehingga dalam pilkada tidak ada yang gratis termasuk suara pemilih. Kemenangan pasangan Maidi-Inda Raya semuanya tidak lepas politik transaksional antara pemilih dengan calon tertentu. Sedangkan menurut teori Weber tentang Tindakan Sosial seseorang, bahwa pilkada merupakan tindakan sosial yang dilakukan oleh seseorang untuk menentukan calon wali kota 5 mendatang. Tindakan sosiali menurut Weber, ada 4 (empat) yakni tindakan social affektif, tindakan social bernilai, tindakan social tradidonal dan tindakan social dengan tujuan tertentu.

Preferensi politik perilaku pemilih dalam menentukan pilihannya bervariasi dalam niat dan motivasi. Sesuai dengan yang disampaikan Weber, bahwa masyarakat memilih walikota mempunyai niatan untuk tujuan dan maksud tertentu. Ada pemilih yang niatnya, untuk tujuan yang luhur dan mulia untuk memilih Kepala Daerah. Oleh karena itu, dalam pilkada tindakan social pemilih bermacam-macam, yang jelas pemilih tidak boleh Golput (Golongan Putih) dan harus menentukan pilihan sesuai preferensi politik partai pilihannya.

\section{KESIMPULAN}

Pemilihan Kepala Daerah (Pilkada) merupakan wahana demokratis, untuk keperluan tersebut seluruh warga negara harus berpartisipasi aktif ,tidak boleh ada yang golput. Pendidikan politik masayarakat yang efektif yakni pada saat pilkada berlangsung, karena pilkada menentukan keberlangsungan negara. Dengan pilkada, peralihan kekuasaan akan berlangsung damai, aman. tentram tanpa ada gejolak, konflik sosail di masyarakat. Preferensi politik pemilih dalam pilkada pasti terjadi,dan hal tersebut merupakan dinamika kehidupsan khusus nya dalam kehidupan social-politik di masayarakat. Semoga hasil pilkada pada tanggal 27 Juni 2018 menghasilkan walikota yang amanah, dapat mengayomi seluruh masyarakat warga Kota Madiun.

\section{DAFTAR PUSTAKA}

Agustino, L. 2007 Perihal IImu Politik, Sebuah Bahasan Memahami IImu Politik. Graha IImu. Jakarta.

Arikunto, S. 2002. Prosedur Penelitian: Suatu Pendekatan Praktisi. Penerbit Rineka Cipta. Jakarta.

Asfar, M. 1995 Pemilihan Umum dan Perilaku Politik. Pustaka Eurike. Surabaya. 
Berger, P.L \& Lukman, T. 1985 Humanisme Sosiologi. Cetakan Pertama Diterjemahkan oleh Dhaniel Dakhidei Penerbit LPES. Jakarta.

Blau, P. 1964. Approaches to Study of Social Structure.The Free Press. New York.

Bogdan R.C \& Bigden S.K. 1982, Qualitatif Research for Education An Introduction to Theory and Method. Alyn and Bacon. Boston.

Bottomore, T. 1992. Sosiologi Politik. Rineka Cipta. Jakarta.

Bradley, H. 1992. Fracture Identity: Canging Patterns of Innequenality. Cambridge.

Budiarjo, M. 2004. Dasar-Dasar IImu Politik. Balai Pustaka. Jakarta.

Cosser, L. 1964 The Fuction of Social Conflict, The Free Pers. New York.
Dahrendorf, R. 1959. Class and Conflict in Industrial Society. Stanford.

Denzin, E. 1971. Political System. New York.

George, R. 2005. Perkembangan Sosiologi dari Klasik Sampai Post Modern. Penerbit Obor. Jakarta.

Hamidi. 2008. Metode Penelitian Kualitatif Pendekatan Praktis Penulisan Proposal dan Laporan Penelitian. Penerbit Universitas Muhamadiyah Malang Pers.Malang.

Harrison, L. 2009. Metodologi Penelitian Politik. Kencana Prenada Media Group. Jakarta.

Huberman, A. Micheil \& Matheu, M. 1992. Analisis Data Kualitatif. UII Pers. Jakarta.

Surbakti, R. 1993. Memahami IImu Politik. Penerbit Gramedia. Jakarta. 